\title{
The Changes of Minahasa's Traditional Marriage Sub Ethnic Tountemboan Society in Raanan Lama Village of South Minahasa
}

\author{
$1^{\text {st }}$ Meity Najoan \\ History Department \\ Faculty of Social Science \\ Universitas Negeri Manado \\ Manado, North Sulawesi \\ meitynajoan@unima.ac.id \\ $4^{\text {th }}$ Ruth Sriana Umbase \\ History Education Department \\ Faculty of Social Science \\ Universitas Negeri Manado \\ Manado, Indonesia \\ ruthumbase@unima.ac.id
}

\author{
$2^{\text {nd }}$ Meike Imbar \\ History Education Study Program \\ Faculty of Social Sciences \\ Universitas Negeri Manado \\ imbarmeike@yahoo.co.id \\ $5^{\text {th }}$ Hetreda Terry \\ History Education Department \\ Fakulty of Social Science, Manado \\ State University \\ Manado, North Sulawesi \\ hetredaterry@unima.ac.id
}

\author{
$3^{\text {rd }}$ Apeles Lexi Lonto \\ Pancasila and Civic Education \\ Department \\ Faculty of Social Science \\ Manado, Norh Sulawesi \\ lexi.lonto@unima.ac.id
}

\begin{abstract}
For Minahasans, marriage is a sacred event, because this event brings together several big families that previously did not know each other to be a new big family. The purpose of this study is to describe and analyze the background of the occurrence changes in the marriage customs of the Minahasa community in Raanan Lama Village. This research uses qualitative descriptive approach. Based on the research finding, it was found that the changes occurring in marriage customs is covering procedures, interest processes, objects in Minahasa marriage customs are due a mixture of traditional and modern elements. Thereby the process of change in marriage custom is very influenced by the people's lifestyle which is cultural, interactional and structural. The background of cultural change in the tradition of the marriage customs of Minahasa community because of their existence contact with other cultures, education, religion, the government policy and the tolerance for deviant acts. With the change channel, it has an impact on Minahasa customary marriage change. So that it is generally concluded that the pattern changes of traditional marriage processions through transfer, integration and acceptance of other cultures caused by contact with the other cultures, educational development, religious norms and community internal policies.
\end{abstract}

Keywords: Marriage, Custom, Culture, Culture Change, Social.

\section{INTRODUCTION}

Like other tribes in Indonesia, Minahasa tribe also has customs as part of cultural wealth. Based on the geographical area and especially from the language aspect used by each sub ethnic, the Minahasa tribe in region of North Sulawesi consists of the following sub-ethnicities: (1) Tountemboan sub-ethnic, (2) Toumbulu sub- ethnic (3) Toulour sub- ethnic (4) Tonsea sub- ethnic (5) Bantik subethnic (6) Tounsawang sub-ethnic (7) Ratahan/Pasan sub-ethnic, and (8) Ponosakan subethnic.

Minahasa ethnicity has a tradition within the marriage process which based on the elements custom. This applies equally to all Sub-ethnic community of Minahasa tribe and the only difference between them are language and the dialect used. Every sub ethnic has each tractive power in carrying out each marriage customary phase. The customary marriage of the Minahasa tribe is one aspect of Minahasa culture that must remain preserved because it has become a characteristic and inherent in Minahasa tribe. So, it really needs to be understood that the distinguishes marriage in each area are the procedures and the marriage customs, marriage traditional ceremonies which different and the elements of trust in each procession are different, that makes Indonesia cultures diverse, which we must preserve.

The meaning of marriage is seen by Minahasa society as a great and sacred event. Great event and sacred because it will meet and associate two big families which don't have family relationship before to be a new big family. The marriage process of son and daughter from two families which have no family relationship is the process of building a new family of two families separate without a family relationship. Marriage binds two big families into a new big family which bound by basic values of kinship and customary law that is adhered together. The process of going marriage must follow strict customary procedures and 
provisions and culminate in marriage ceremony. In Mina marriage custom is known several procedures and provisions such as batunangan time, the period of marriage and marriage ceremony. In the period of batunangan, young people of Minahasa are free and independently look for potential husband and prospective spouses. Youth must be active and free without parents/family coercion looking for and finding the girl who becomes "Kaleos" (fiancée). The basic word "kaleos" is "leos" means good, holy, noble, great. So, the youth free and independent, in the sense of without coercion from parents and family to accept/reject a youth who is intend to make her as a fiancée.

All marriage events from the request to marriage ceremony which mentioned above if it runs smoothly all accompanied by music and traditional art performances. However, in development occurs changes in the process of marriage custom. When the western culture enters and religion that brought by Portuguese, Spanish and Dutch colonials, then joined affect the customary procedures of Minahasa marriage. Where the marriage custom has changed and then adjusted and combined with the ceremony/worship according to the religion of the bride.

However, as the case in the life of society in general that there is nothing eternal, everything changes according to the times. Minahasa community also experienced various changes and couldn't continue to uphold their culture and customs. Despite the philosophy of Minahasa customs as mentioned above continues to live along epoch, but the cultural values and customs that have been the social law of Minahasa community, it has undergone changes and dynamics transformation, whether it occurs quickly or slowly. Today, based on the author's observations that various changes have taken place in Minahasa community included dealing with implementation and pattern of Minahasa customs marriage. The values of such marital customs which sacred is maintained by previous generations, now it has changed so that it gives birth new form, although the traditional nuance still exists and maintained.

The reality of changes that occur in a society is an important part of the social change paradigm. This is related with the concept that a change which occur in society from certain conditions towards other conditions of course bring certain effects into the community social institutions. This context can be associated with the reality that occurs in Minahasa customs marriage. Unwittingly as mentioned above, that the caused of various factors that exist, the inheritance of Minahasa marriage customs from their ancestors, it has now shifted, changed and instead there is something that is forgotten.

Various internal factors such as aspect advancement of community education for example has become the background of attitude change followed by the desire to change individually and collectively. On the other hand, changes also occur caused by other internal factors such as economic factors and time efficient as well as social factors resulting in changes of community social structure has stretched individual and collective relationships within Minahasa community. Likewise, various exogenous factors like the exit, mass media and the flow of technology bringing various modernizations to this area. No less importantly, the opening of various other accesses as channel of changes as well are factors that occur in the acculturation process diffusion which gave birth to new forms of culture and marriage customs in Minahasa community.

What happens in Minahasa community marriage customs Tountemboan Sub Ethnic shows that in society has changed in the way governance implementation and the fading of marital customs. Generation at present most of them have not used the customary marriage procedures. As already stated above, that the changes occur in customary settings marriage, where if the previous nuances of the event customary marriage, for example if it was first made sabua (set up a tent covered with tarpaulin or zinc), and the inside scattered various kinds of flowers, then in Sabua there are lodges with katu leaves and bamboo, long dining table decorated with banana leaves, stand coconut shoots on the aisle, and don't miss the wedding cake place, however currently wedding events are made in large buildings, with a modern cuisine menu. Previously the customary marriage events accompanied by bamboo music (typical music of Minahasa traditional), maengket dances and kabasaran/cakalele dances, now replaced with modern musics.

Relating to this change, according to Macionis in [1] defines social change as a transformation in the community organization, in mindset and in behavior on certain time. While [2] suggests that social change is interpreted as a variation of life ways that has been accepted, both because of geographical changes, material culture, population composition, ideology, or because of diffusion or new discoveries in the community. Soerjono Soekarto formulated that social change are all changes in community institutions in a society, which affect the social system, including the 
values, attitudes, and the recognition patterns among the groups in society.

Goodenough in [3] suggests, that marriage is a transaction which produce a contract in which a person (male or female, corporative or individually personally or through a representative), has the right to continue sexual intercourse with a woman. This right has priority over the right to associate the sex that is being owned, or what is later obtained by people towards the woman (except those through such transactions), until the transaction of contract result ends and the woman is concerned considered eligible to give birth a child.

Marriage in the view of Minahasa community as a great and sacred event because it brings together and associated two big families which previously have no family relationship to be a new big family. The marriage process of son and daughter of two families which have no family relationship is the process of building a new family from two separate families without a family relationship. Marriage binds two big families into one new big family which is bound by the family basic values and customary law that is adhered together. The process of going marriage must follow the procedures and the strict customary provisions and culminating in marriage ceremony.

Thereby the importance of this research is to describe and analyze the changes background in marriage customs of the Minahasa community Tountemboan Sub-ethnic in Raanan Lama Village, West Motoling Sub-district, South Minahasa Regency.

\section{RESEARCH METHODS}

Researh about Minahasa community marriage custom Tountemboan sub-ethnic uses qualitative descriptive approach. The data analysis uses Miles Huberman analysis model.

\section{RESULTS AND DISCUSSION}

As it is known that marriage is seen by the Minahasa society as a great and sacred event. Great and sacred events because it will meet and associated two big families which previously have no family relationship to be a new big family. The marriage process of son and daughter of two families which have no relationship is the process of building a new big family from two separated family without a family relationship. Marriage binds two big families to be a new big family which is bound by kinship basic values and customary law that is obeyed together. The process of going marriage must follow the procedures and provisions customary strict and culminating in marriage ceremony.

Every culture and culture at a time will change for various reasons. As a part of a culture, the marriage system especially concerning to the rules that do not close the possibility of changing along with the progress of human thought and the demands of human life are included age dynamics. Tountemboan Sub-Ethnic marriage tradition, as a part of Minahasa community culture cannot avoid the changes. Changes to the marriage customary traditions of Tountembaoan sub-ethnic is marked by several changes as follow:

\section{A. Changes to the implementation process of marriage customary.}

In essence, there has been a change in the process of implementing marriage customs which carried out in Minahasa land. This is inseparable from the influence of mindset and the era dynamics which continues develop. This change occurs in Posanan/pingitan activity, which always done a month before the wedding event, but today it is done one or two days approaching the wedding.

The next change, namely in the past bathing is always done in the shower, however currently the bathing process is done in the bathroom of the house. Else, the wedding should be held in a day to save time, effort and costs. Other thing which follows the changes is the ritual of throwing hand flowers and dance free program accompanied with traditional music used as a symbolic activity. Including bridal's toiletries use bath soap purchased from the store and wash the hair using shampoo. With regarding the changes above, Sztompka (2010), explains if the life in society never been released with the name of change in all life sector. Changes always exist and it scopes quite broad can be mindset, attitude and the behavior in everyday life.

Marriage custom as part of social life is something which dynamic, always changing, and thus not static. As well as a society entity in a community, always moving, evolving and changing towards the perfection direction. [1], states that the society always change at all levels internal complexity. Although in order to change towards the perfection it must bring impact to all social systems which so far it has been adhered and maintained. It is causality relationship, mutual casual relationships which related each other. Which means what happens with the Minahasa community currently in marriage procedure at this time, is a development process from the community in the past. As explained by [1], that the society exists every time from the past to the future. His presence is precisely through the phase 
between what was happened and what will happen. Now in society contains influence, freedom and past plagiarism and seeds and potential for the future. Community processing implicitly means that the previous phase related to the present causation and the present phase is the causation requirement which determine the next phase.

B. Changes in the use of custom objects which bring at the wedding event

Explained earlier, that there are many objects which bring at the moment of Minahasan's wedding Tountemboan Sub-Ethnic. In outline, it can be stated that there has been a change in this aspect. Where in the stage of engagement until marriage always uses several things.

Relating to the objects which bring in wedding process, there is also changing in the event wedding. If in the past, the Pinang ceremony, the Tawa'ang ceremony are often done and drink water used a bamboo segment (kower). There is also a ceremony to cut firewood. The firewood that has been brought will be split as a food and clothing symbol. In Tontemboan sub-ethnic especially in Raanan Lama Village, the firewood that was split only three cut firewood. However, at this time the process and the objects such as areca nut, tawa'an tree, firewood and the glass which made from young bamboo segment is no longer used again.

Based on the condition above related to the objects changing, this is in line with the opinion of William F. Ogburn in [4] who suggested that the scope of the social changing is quite broad not only limited to the material changes but also related to non-material changes. Social change includes technology change that caused the material environment change and regulate it, so that inciting changing or habits modification and social institution. In the empirical world, between society and culture are a unified whole.

C. Pattern change of making a proposal in marriage custom tradition

Besides some of the changes above, there is changing in process and the existing pattern of making a proposal in Minahasa marriage custom. If previously in the period of engagement, the Minahasa's youths are free and independently looking for a prospective husband and prospective wife. Youth must be active and free from coercion of parents/family and finding the girl who became his fiancée.

If later a man and a woman fall in love and agreed to establish a relationship, then they have gone through "engagement period" until the moment "making a proposal". In this period, the youth may visit the woman's house and go outside together with the permission of the woman's parents. On the contrary, during this engagement the woman is prohibited for visiting the man's house. However, in current condition, young man and young woman can be visited to each other's family. The reason is if the young woman went to the man's house, the man's family can know farther the behavior of the woman quickly, so that in the next process it can be carried out well.

Then, when the engaged goes well, the time comes for making a proposal. But in the development of the process, it doesn't take place properly. If pay attention to the analysis finding in the previous chapter that usually the period of making a proposal done by the man's family at the house of woman at the agreed time. The determining good day or in Minahasa language called "endo leos" led by a "walian" or religious leader according to Minahasa tradition. But for now, it is no longer determined by walian, but with mutual agreement between the two parties by determining the day for process of making a proposal.

Another thing that also change is the process when want to do the proposal. In the process of making a proposal traditionally, usually the house of the young woman is dark, quite and closed. As if there's no one and don't know if anyone will come to visit. The house's door will be opened when there was a reply to the interlocutor as a respect gesture and was replied from inside the house by the spokeswoman, then resumed by youth spokesman "awean wo'on pa roman" which means there is something that needs to be discussed with the family at this place. After being invited to enter the woman's house by the spokeswoman then the woman's family welcomes the guests kindly. The white plate was put on the table as the symbol of sincerity and the purity of heart to entertain guests, besides that to show that the daughter is still pure and after the white plate was put on the table, was greeted with a piece of money no matter the price by the youth as a symbol of respect and honor the woman and her family. The current reality, the house's door being knocked has been opened wide, the group was immediately invited to enter the house as soon as they arrive at the party's house young woman, while welcome to sit. That is the situation of the house is no longer silent and dark but it is ablaze.

Changes in concepts or norms in Minahasa customary marriage, according to [5] view which states that humans are social creatures and normative beings that are meaningful submit to the norms of the group. Norms internalization mean identifying himself with the existing or prevailing 
norm, so that he takes over the norm system including the social attitudes existing in the society.

Based on this condition, it can state that modernism which based on the Minahasan's attitude who want to get advance then get a response and support from the various supporting factors. The entry of various ethnic groups, the education advancement, technology, and modernism to Minahasa also encourages the creation of a change in the marriage tradition. Based on the view above, then it can be stated that one of the factors that has the most instrumental role which brought change in Minahasa custom marriage is because the existing of encouragement that want to change to adjust to change existing environment. This is similar to what [6] stated that the occurrence changes in society is based on the desire to change from the community itself, as a form to be able to adjust yourself with the demands of new needs that exist in the society which must be fulfilled immediately.

Thereby it can be stated that the changes in procedures processes of making a proposal, the objects in Minahasa custom marriage due to intermingling traditional and modern elements. The lifestyle of the society in Minahasa that is very developed form the implementation of Minahasa wedding ceremonies, unite the whole process of the traditional marriage ceremony that carried out only in one day. The change in the procession pattern customary marriage is influenced by the people's lifestyle which is cultural, interactional and structural.

Thus, changes in procession pattern of Minahasa custom marriage was motivated by the contact factor with the other cultures, education, religion, the government policy and tolerance for deviant acts. The existence of communication patterns, technological advances, mass media and education play an important role in changes in the Minahasan custom marriage procession. With the existence of changes channel impact on the changing of Minahasa custom marriage. Changes in the pattern of traditional marriage processions through transfer, integration and acceptance of the other cultures caused by the contact with the other cultures, the education development, religious norm and the existence of policy.

\section{CONCLUSION}

Based on the discussion above, it can be concluded that the changes that occur in marriage customs include procedures, the process of solicitation, the objects in Minahasa marriage customs due to assimilation between traditional and modern elements. This is also because influenced by the people's lifestyle in Minahasa which very developed affects the implementation of Minahasa wedding ceremony, uniting the whole process of traditional marriage ceremony that carried out only in a day. Thereby the changes process in marriage custom influenced by the society's lifestyle that is cultural, interactional and structural. The background of cultural change in Minahasa custom marriage tradition Tountemboan sub-ethnic occurs because of the contact with the other cultures, education, religion, the government policy and the tolerance against deviant acts. Then followed by the communication pattern, technological advances, mass media and education play an important role in the occurrence changes in Minahasa custom marriage procession. Thus, the existence of changes channel has an impact to the changing of Minahasa custom marriage. So that it is generally concluded that the changing pattern of the traditional marriage processions through transfer, integration and the acceptance of other cultures caused by contact with other cultures, educational development, religious norm and the policy in society.

\section{ACKNOWLEDGMENT}

Thank you we convey to the informants and the customary figures, religion and the government figures in the Raanan Lama Village for the willingness to provide information and have support the implementation of this research.

\section{REFERENCES}

[1] P. Sztompka, Sociology of Social Change. Jakarta: Prenada, 2010.

[2] G. C. Soemardjan, S., Breazeale, K., \& Chu, Cultural change in rural Indonesia: Impact of village development. Honolulu.: Yayasan IlmuIlmu Social, Jakarta,[and] East-West Center, 1993.

[3] R. M. \& G. S. Keesing, Cultural Anthropology A Contemporary Perspective, II. Jakarta: Arlangga, 1992.

[4] Hatu R, "Changes in the cultural social of Rural Communities (A Theoretical-Empirical Review)," J Inov [Internet]., vol. 8 (4), no. 11, pp. 1-11, 2011.

[5] C. D. Wulansari, Sociology: Concept and theory. Jakarta: Refika Aditama, 2009.

[6] S. Soerjono, Sociology of an introduction. Jakarta: PT. Rajawali., 1990. 